\title{
APPLICATION OF COMPUTER SIMULATION FOR OPTIMIZATION OF TECHNOLOGICAL PARAMETERS OF PRECISION FORGING
}

\author{
Mária Kapustová, Ingrid Görögová
}

Original scientific paper

The paper deals with the optimization of technological parameters of precision forging in closed die using computer simulation with the aim to achieve high dimensional accuracy and surface quality of drop forgings. The research has been applied on spur gears with a hub. This type of mechanical part has been chosen because of its wide application in machine industry. Shape of this drop forging is suitable for the precision forging technology, as well. Case hardening steel $16 \mathrm{MnCr} 5$ has been selected as a common material used for drop forging production. Computer simulation is a useful solution for prediction of the forging process development and material behaviour in closed die cavity. The numeric simulation has been used for the optimization of billet shape and dimensions and observation of plastic flow in closed die cavity at warm die forging. Suitability of material flow in die cavity, effective plastic strain and temperature of drop forging have been evaluated by means of simulation software Simufact.forming. To meet all requirements on accuracy of drop forgings it is necessary to take into consideration optimization of technological parameters using computer simulation.

Keywords: closed die; computer simulation; forgeability; spur gear; precision warm die forging; upsetting test

Primjena simulacije računalom u optimizaciji tehnoloških parametara kod preciznog kovanja

Izvorni znanstveni članak Rad se bavi optimizacijom tehnoloških parametara kod preciznog kovanja u zatvorenom kalupu primjenom simulacije računalom s ciljem postizanja visoke dimenzionalne točnosti $\mathrm{i}$ kvalitete površine otkivaka dobivenih kalupnim kovanjem. Istraživanje se provodilo na čelnicima s ravnim zubima s glavinom. Taj je tip strojnog dijela izabran zbog njegove široke primjene u strojarstvu. Oblik takvog otkivka također je pogodan za tehnologiju preciznog kovanja. Čelik za kaljenje $16 \mathrm{MnCr} 5$ odabran je kao materijal za proizvodnju kalupnim kovanjem. Simulacija računalom je korisno rješenje za predviđanje odvijanja postupka kovanja i ponašanja materijala u zatvorenoj šupljini kalupa. Numerička simulacije je primijenjena u optimizaciji oblika i dimenzija trupca te promatranja plastičnog tečenja u zatvorenoj šupljini kod kovanja u kalupu. Odgovarajući tok materijala u kalupu, učinkovita plastična deformacija i temperatura kalupnog kovanja procijenjeni su pomoću simulacijskog softvera Simufact.forming. Kako bi se zadovoljili svi zahtjevi vezani za točnost otkivaka dobivenih kalupnim kovanjem potrebno je uzeti u obzir optimizaciju tehnoloških parametara primjenom simulacije računalom.

Ključne riječi: čelnik s ravnim zubima; ispitivanje sabijanjem; precizno toplo kovanje u kalupu; simulacija računalom; sposobnost kovanja; zatvoreni kalup

\section{Introduction}

Technological processes of drop forgings production using die forging must be still analysed and improved to meet all customers' requirements, environmental legislation and international competition. Production of drop forgings by the precision forging technology is the main area of research and development within the advanced methods of the drop forgings production. Design and production of accurate drop forgings, which vary minimally in the shape of the final parts appropriate for the assembly, brings optimization of production costs and production times, which is the main aim of the precision forging technology.

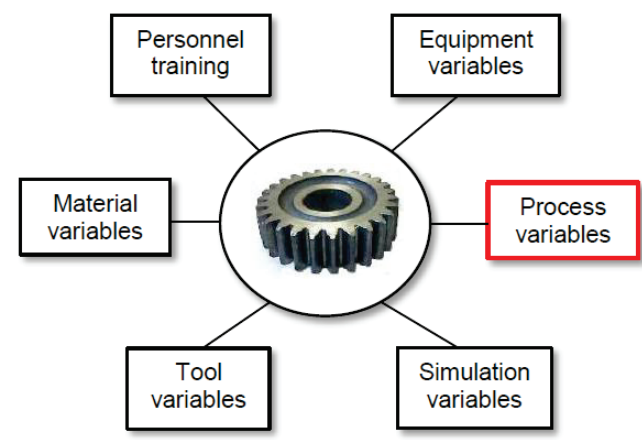

Figure 1 Variables which have influence on accuracy of drop forgings

Precision forging can be used for the manufacturing of simple or complex drop forgings with high accuracy. They can be divided into drop forgings produced net- shape or near net-shape (with minimal or no cutting operations). Precision forging can be used in open dies with standard flash as well as in closed dies for forging without flash. However, application of precision warm forging in closed die provides best conditions for achievement of high accuracy of drop forgings and high efficiency of forged material. Exact volume of billet and suitable compensation method for excess material are necessary for proper performance of precision forging development in closed dies $[1 \div 3]$.

\section{Parameters of precision die forging}

There are many technological and other process parameters which have influence on accuracy of drop forgings. Technological parameters as shown in Fig. 1 have important position in the design of manufacturing of drop forgings using precision forging. This contribution will focus on research of selected evaluated parameters: billet shape, warm forging temperature and shape of forging tool. Design of the forging tool is closely related to the designed billet shape. Proper design of compensation method of excess billet material is very

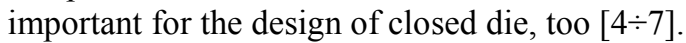

High dimensional accuracy and surface quality of drop forgings at the suitable loading of forging die can be achieved by reduction of forging temperature in the area of warm forging. Use of warm forging processes is very interesting for all manufacturers of accurate drop forgings. The temperature range concerning steel at warm forging processes is approximately from 600 to $800{ }^{\circ} \mathrm{C}$. 
The mentioned temperature interval is quite narrow; therefore the research of steel formability and forgeability is important for determination of upper forging temperature $[8,9]$.

\section{Forgeability of steel at warm temperatures}

The research of steel plasticity at the temperatures of warm forging was performed on $16 \mathrm{MnCr} 5$ steel alloy. It is chromium-manganic structural steel, suitable for case hardening, which has appropriate warm ductility, after spheroid zing also the cold ductility. It is used for production of case hardened machine parts with very hard surface and after quenching also with high rigidity of core. This type of steel is suitable for precision forging according to its chemical composition and mechanical properties. Case hardening steel $16 \mathrm{MnCr} 5$ has been selected as a forged material. Chemical composition of steel is shown in Tab. 1.

Table 1 Chemical composition of steel (wt $\%)$

\begin{tabular}{|c|c|c|c|c|c|c|c|c|}
\hline El. & $\mathrm{C}$ & $\mathrm{Mn}$ & $\mathrm{Si}$ & $\mathrm{Cr}$ & $\mathrm{Ni}$ & $\mathrm{Mo}$ & $\mathrm{W}$ & $\mathrm{P}, \mathrm{S}$ \\
\hline Co. & 0,165 & 1,32 & 0,25 & 0,9 & 0,139 & 0,04 & 0,02 & 0,015 \\
\hline
\end{tabular}

For the verification of steel forgeability at warm forging, the technological test of upsetting according to Židek is used. The test is based on deformation of cylindrical test sample with four notches at defined temperatures [10]. Samples with diameters of $\varnothing 30 \times 40$ $\mathrm{mm}$ are deformed to the extent of one third of their height (i.e. height dimension of the sample after upsetting is approximately $27 \mathrm{~mm}$ ). The presence of cracks in notches is evaluated.

The test author Židek recommends five classification degrees used for forgeability evaluation according to appearance of cracks in cylinder notches:

1 without cracks (good forgeability)

2 small separated cracks (lowered forgeability)

3 small cracks in all notches (medium lowered forgeability)

4 medium cracks in all notches (downgraded forgeability)

5 big cracks (fractures) in all notches.
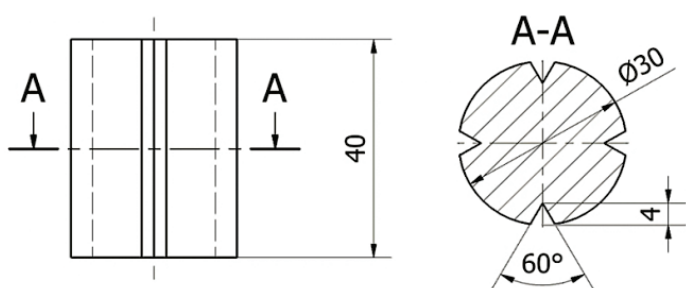

Figure 2 Shape and dimensions of test sample

Warm forge ability of steel is considered by mean value, which is given by classification level according to examined temperatures. Testing samples were made from a bar heat rolled, which was provided without any heat treatment. In order to harmonize mechanical properties and obtain fine-grained structure it was necessary to anneal the testing cylinders. The shape and dimensions of a test sample are shown in Fig. 2.

The upsetting tests were performed at selected temperatures $600,650,700$ a $750{ }^{\circ} \mathrm{C}$, whereas three testing samples were examined at each temperature. The cylinders with notches were upset on vertical forging press LZK 1600 by one third of its height and the appearance of cracks in notches was evaluated. Accordingly the appearance of cracks in notches according to classification degrees at particular temperatures was evaluated - the results are stated in Tab. 2 .

Table 2 Evaluation of cracks in notches of sample

\begin{tabular}{|c|c|c|c|c|}
\hline Temperature $\left({ }^{\circ} \mathrm{C}\right)$ & 600 & 650 & 700 & 750 \\
\hline Classification degree & 1 & 1 & 1 & 2 \\
\hline
\end{tabular}

Prior to the laboratory experiment performance a computer simulation of technologic test was realized by means of simulation program Simufact.forming. The simulation confirmed correct selection of warm temperatures, as testing samples showed good forgeability and after upsetting in notch area no defects or cracks were revealed. An example of a cylinder deformed during the experiment and simulation of upsetting process is shown in Fig. 3 and the simulation results are shown in Fig. 4 and Fig. 5.

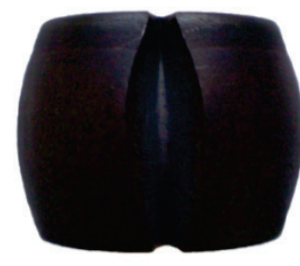

a)

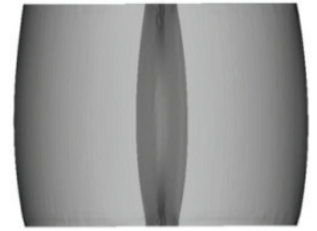

b)
Figure 3 Shape of deformed test sample at temperature $700{ }^{\circ} \mathrm{C}$ a) laboratory experiment b) computer simulation

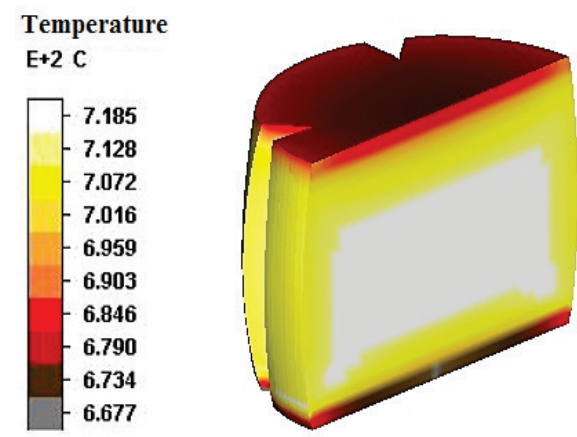

Figure 4 Simulation of the temperature field after upsetting at $700{ }^{\circ} \mathrm{C}$

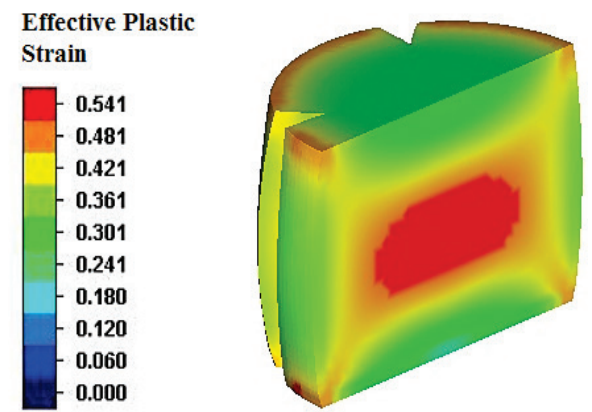

Figure 5 Distribution of the effective strain over the sample volume after upsetting at $700{ }^{\circ} \mathrm{C}$

Forgeability of low-carbon steel $16 \mathrm{MnCr} 5$ in warm temperature interval was evaluated on the basis of mean value concerning classification degrees for particular 
temperatures. Reached value 1 means good forgeability of $16 \mathrm{MnCr} 5$ steel at warm conditions with regard to temperatures 600,650 and $700{ }^{\circ} \mathrm{C}$. Random cracks in notches appeared at testing temperature $750{ }^{\circ} \mathrm{C}$. The mentioned temperature is not recommended as upper forging temperature.

\section{Design of the billet and the forging tool}

Research on the optimization of the technological parameters (dimensions of billet, tool design) of precision forging in closed dies has been applied on spur gears with straight teeth and a hub. Shape of die cavity of forging tool and compensation method of excess material relate to the design of billet shape. Shape of drop forging of the given spur gear is shown in Fig. 6.

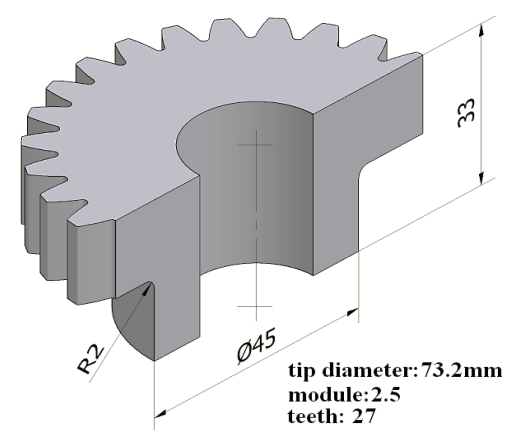

Figure 6 Accurate drop forging -spur gear

Manufacture of drop forging - spur gear consists of the single forming operation, i.e. precision warm forging in closed die from ring billet. Two essential alternatives of ring billet dimensions (Tab. 3) were proposed, these variants determine also the method of inserting the billet into die cavity, as Fig. 8 shows it.

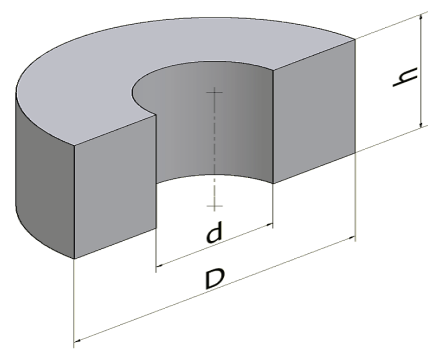

Figure 7 Ring-shaped billet

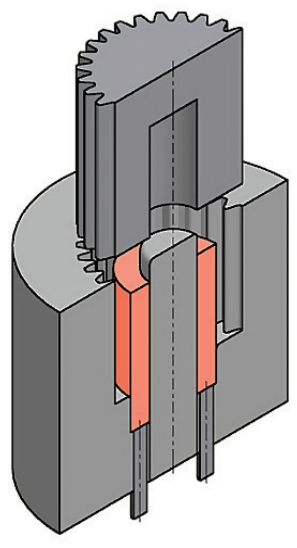

a)

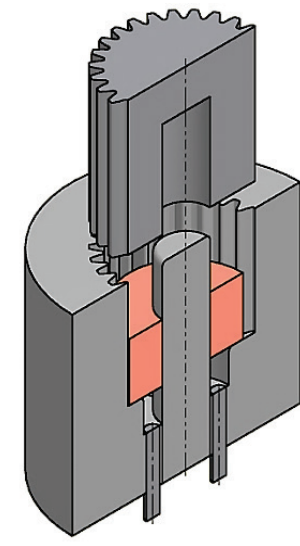

b)
Figure 8 Design of the forging tool with possible alternatives of billet dimensions
Table 3 Dimensions of ring-shaped billet

\begin{tabular}{|c|c|c|c|}
\hline \multirow{2}{*}{ Alternative } & \multicolumn{3}{|c|}{ Dimensions of billet (mm) } \\
\cline { 2 - 4 } & $d$ & $D$ & $h$ \\
\hline a) & 25 & 45 & 68 \\
\hline b) & 25 & 60 & 32 \\
\hline
\end{tabular}

The drop forging will be manufactured without creation of a web. Therefore, ring billet has been designed. Two basic alternatives of the ring billet dimensions suitable for precision die forging are illustrated in Fig. 8. The following compensation method has been designed for both variants of billet dimensions:

- axial compensator placed between lower and upper die, illustrated in detail 1 in Fig. 9, is suitable for the alternative in Fig. 8a),

- container compensator placed bellow a hub of drop forging, illustrated in detail 2 in Fig. 9, is suitable for the alternative in Fig. 8b).

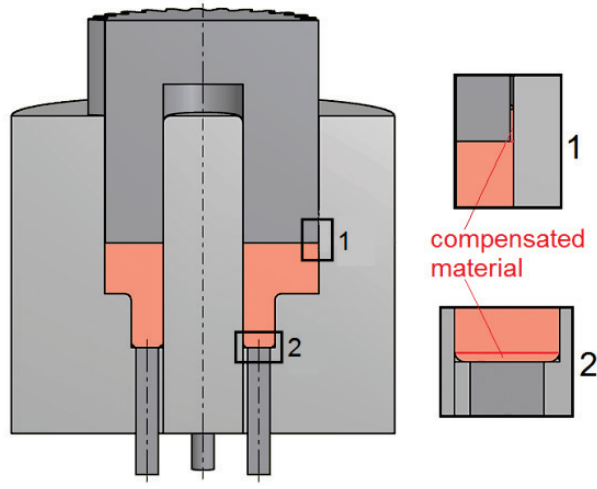

Figure 9 Method of excess material compensation

\section{Optimization of the parameters with the use of simulation}

Computer simulation is a useful solution for prediction of process development and material behaviour in die cavity. In this way, it is possible to optimize the tool shape and design technological process and by that considerably reduce financial costs of preproduction stages and production itself. Optimization of ring billet dimensions has been realized using the simulation program Simufact.forming. Suitability of the billet shape and dimensions has been evaluated primarily from the aspects of material flow in die cavity. Simufact.forming program is suitable for the simulation of hot, warm as well as cold bulk forming processes $[11 \div 13]$.

For starting the simulation in the preprocessing stage it is necessary to define the input data properly:

- process: warm forging in closed die

- $\quad$ billet material: DIN 17210 (1.7131)

- tool material: ASTM A 681 (H13)

- billet temperature: $700{ }^{\circ} \mathrm{C}$

- tool temperature: $250{ }^{\circ} \mathrm{C}$

- coefficient of friction: 0,2 .

Simulation results as illustrated in Fig. 10 show that the material flow in closed die cavity at the forging with ring billet placed in the bottom of a hub is incorrect because of lap formation. We may state that the designed dimensions of billet in Fig. 8a) are incorrect and they do 
not ensure faultless manufacturing of the given drop forging by warm forging.

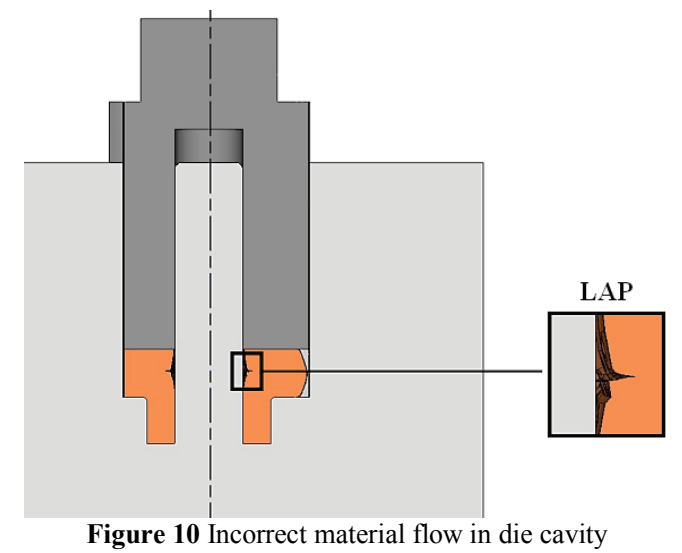

Computer simulation of material flow in die cavity where the ring billet is placed on the bottom surface of a ring with toothing is shown in Fig. 11.

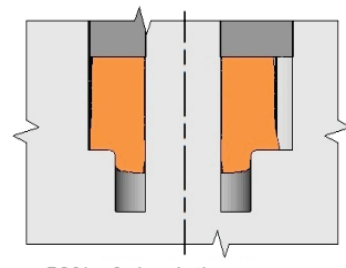

$50 \%$ of simulation process

Figure 11 Correct material flow in die cavity

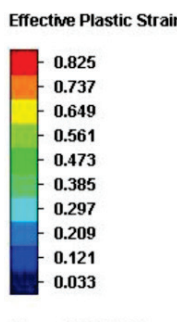

$\begin{array}{ll}\text { Max. } & \text { 8.246E-001 } \\ \text { Min. } & \text { 3.280E-002 }\end{array}$

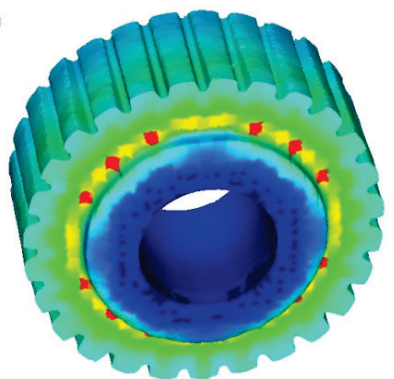

Figure 12 Effective plastic strains at the $50 \%$ of simulation process

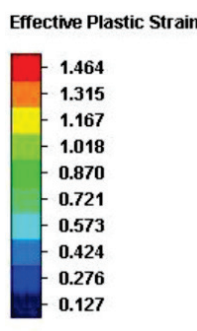

$\begin{array}{ll}\text { Max. } & 1.464 \mathrm{E}+000 \\ \text { Min. } & 1.274 \mathrm{E}-001\end{array}$

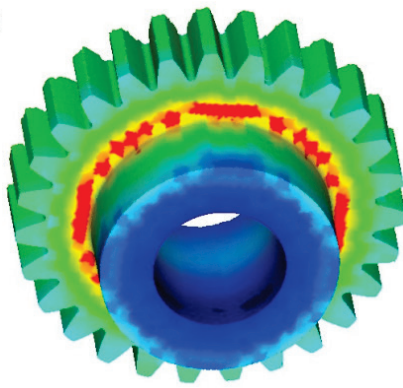

Figure 13 Effective plastic strains at the $100 \%$ of simulation process

Suitable material flow in die cavity at the temperature of warm forging (i.e. $700{ }^{\circ} \mathrm{C}$ ) for the dimensions of ring billet shown in Fig. 8b) has been evaluated using computer simulation [14]. Both the progress of effective plastic strain and temperature areas of drop forging, where the ring billet fits on the bottom surface of a ring with toothing have been evaluated. The simulation results are shown in Figs. $12 \div 15$. The numeric simulation proves that the highest values of the effective plastic strain and temperature have been observed in the area of the fillets from the ring to the hub.

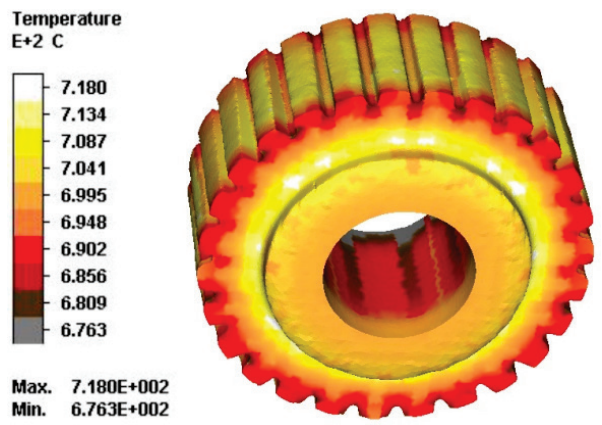

Figure 14 Temperature fields at the $50 \%$ of simulation process

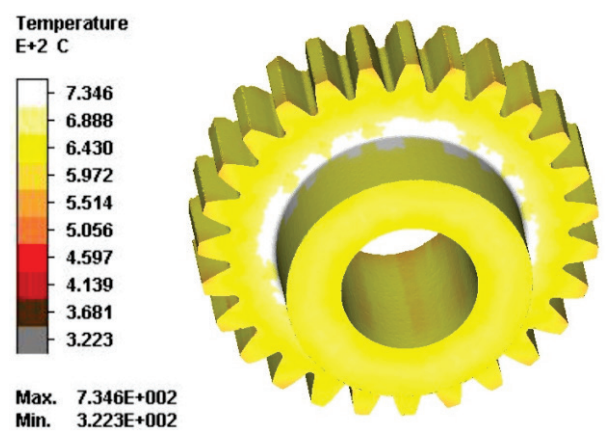

Figure 15 Temperature fields at the $100 \%$ of simulation process

\section{Conclusion}

The selection of billet dimensions and design of the forging tool is very important for the optimization of technological parameters of precision die forging process as well as for forging tool life $[15,16]$. Two basic alternatives of ring billet dimensions and the shape of die cavity for the production of given drop forging of spur gear have been designed. Incorrect material flow in die cavity where ring billet fits on the bottom of a hub has been detected using computer simulation. The lap has been created near the forging spike in the area of ring with toothing. Optimal material flow in die cavity may be achieved at precision die forging in closed die at warm conditions $\left(700{ }^{\circ} \mathrm{C}\right)$ with the use of ring billet placed on the ring and container compensator placed bellow a hub. Warm forging is useful in production practice in order to achieve considerable savings and reduce final price of a drop forging. Optimization of technological parameters using computer simulation is important for development of the advanced technology of precision forging.

\section{Acknowledgements}

This article has been created with the support of projects VEGA 1/0669/15 and FormTool MANUNET2014-11283: Innovative methods of sheet metal forming tools surfaces improvement - R\&D.

\section{$7 \quad$ References}

[1] Altan, T. et al. Cold and Hot Forging: Fundamentals and Applications. Ohio: ASM International, 2005. 
[2] Kapustová, M. Innovations in production trends for drop forging. Scientific Monographs. ${ }^{\text {st }}$ ed. Köthen: Hochschule Anhalt, 2010.

[3] Doege, E.; Bohnsak, B. A. Closed die technologies for hot forging. // Journal of Materials Processing Technology. 98, (2000), pp. 165-170. DOI: 10.1016/S0924-0136(99)00194-6

[4] Douglas, R.; Kuhlmann, D. Guidelines for precision hot forging with applications. // Journal of Materials Processing Technology. 98, (2000), pp. 182-188. DOI: 10.1016/S09240136(99)00197-1

[5] Milutinovič, M. et al. Precision forging - tool concepts and process design. // Journal for Technology of Plasticity. 33, 1-2(2008), pp. 73-88.

[6] Brooks, J. W. Friction during precision forging of high temperature aerospace materials. // Materials Science and Technology. 28, 5(2012), pp. 528-531. DOl: 10.1179/1743284711Y.0000000119

[7] Lazić, V.; Sedmak, A.; Aleksandrović, S.; Milosavljević, D.; Čukić, R.; Grabulov, V. Reparation of the damaged forging hammer mallet by hard facing and weld cladding. // Tehnicki vjesnik-Technical Gazette. 16, 4(2009), pp. 107113.

[8] Behrens, B. A. Warm forging: new forming sequence for the manufacturing of long flat pieces. // Production Engineering Research and Development. 2(2008), pp. 261268. DOI: $10.1007 / \mathrm{s} 11740-008-0114-4$

[9] Hosford, W. F.; Caddell, R. M. Metal Forming. Mechanics and Metallurgy. Fourth edition. New York: Cambridge University Press, 2011. DOI: 10.1017/CBO9780511976940

[10] Forejt, M.; Píška, M. Theory of machining, forming and tools. Brno: CERM, 2006.

[11] Dixit, P. M.; Dixit, U. S. Modeling of Metal Forming and Machining Processes by Finite Element and Soft Computing Methods. London: Springer Verlag, 2008.

[12] Behrens, B. A. Finite element analysis of die wear in hot forging processes. // CIRP Annals Manufacturing Technology. 57, (2008), pp. 305-308. DOl: 10.1016/j.cirp.2008.03.087

[13] Song, J. H.; Im, Y. T. Process design for closed-die forging of bevel gear by finite element analyses. // Journal of Materials Processing Technology. 192, (2007), pp. 1-7. DOI: 10.1016/j.jmatprotec.2007.04.081

[14] Lee, R. S.; Jou, J. L. Application of numerical simulation for wear analysis of warm forging die. // Journal of Materials Processing Technology. 140, (2003), pp. 43-48. DOI: 10.1016/S0924-0136(03)00723-4

[15] Cai, J. Alternative die designs in net-shape forging of gears. // Journal of Materials Processing Technology. 150, 12(2004), pp. 48-55. DOI: 10.1016/j.jmatprotec.2004.01.019

[16] Behrens, B. A.; Odening, D. Process and tool design for precision forging of geared components. // Journal of Material Forming. 2, (2009), pp. 125-128. DOl: 10.1007/s12289-009-0577-7

\section{Authors' addresses}

Mária Kapustová, doc. Ing. PhD.

Slovak University of Technology in Bratislava, Faculty of Materials Science and Technology, Institute of Production Technologies,

J. Bottu 25, 917 24, Trnava, Slovak Republic,

E-mail: maria.kapustova@stuba.sk

Ingrid Görögová, Ing. PhD.

Slovak University of Technology in Bratislava, Faculty of Materials Science and Technology, Institute of Production Technologies,

J. Bottu 25, 917 24, Trnava, Slovak Republic,

E-mail: ingrid.gorogova@stuba.sk 